\title{
学んでつなげる糖尿病の基礎知識
}

一教育現場からのアプローチ一

村上 理, * 松野良智, 鈴木素邦, 木暮喜久子

\section{Learn and Relation, Basic Knowledge of Diabetes -Approach from an Educational Front-}

\author{
Aya Murakami, * Yoshinori Matsuno, Soho Suzuki, and Kikuko Kogure \\ Educational Foundation Igaku Academy Yakugaku Seminar, Imafuku 2746, \\ Kawagoe, Saitama 350-1151, Japan
}

(Received September 22, 2010)

\begin{abstract}
A six-year program started in 2006, and Computer Based Testing (CBT), Objective Structured Clinical Examination (OSCE) and long-term practical training were introduced into the pharmacy education. As a member of the team medical care, we participate in medical care positively, and a pharmacist now wanted is who could be able to communication well with the medical worker and the patient has. We have the results of 32 years as a cramming school for the pharmacist national examination candidate. We have life study center, a hospital, a pharmacy, and the publishing division. Firstly we taking part in the education, learn the present conditions, the clinical cases, and stream down it to a student, and it is necessary to send it in the future of a pharmacy and the pharmacist. Therefore we carry out studying society of the prescription, an experience of the compounding of medicines training, participation to the life study. At this symposium, we give a lecture on diabetes based on the situation of pharmacy education, the clinical spot, medical supplies development. We introduce condition of a patient physiology of the diabetes, the difference of the model, a symptom, inspection, efficacy of the medicine, a side effect in that. Thus, we want to propose some technical skills for relating these clinical conditions in the future education.
\end{abstract}

Key words_— pharmacy education; team medical care; diabetes; six-year program; long-term practical training; Objective Structured Clinical Examination (OSCE)

\section{1.はじめに}

薬学教育は平成 18 年度より 6 年制が導入され, Computer Based Testing（CBT ; 知識及び問題解決 能力を評価する客観試験），Objective Structured Clinical Examination（OSCE；技能・態度を評価す る客観的臨床能力試験), 薬剂師生涯学習 (卒後教 育）等が起動し始めた.

6 年制導入により薬剤師国家試験においても求め られる薬剤師像がより明確化された。薬剤師法, 第 三章「試験」の第十一条において，「試験は，薬剂 師として必要な知識及び技能について行なう」1) と 記載されており，4年制薬剂師国家試験の合格基準

学校法人医学アカデミー薬学ゼミナール（†350-1151 埼玉県川越市今福 2746)

*e-mail: murakami@yakuzemi.ac.jp

本総説は, 日本薬学会第 130 年会シンポジウム S15 で 発表したものを中心に記述したものである.
では「薬剂師国家試験は，薬剂師として必要な知識 及び技能について試験するものであり，総合成績が 一定水準以上であり，かつ，新たに設ける四つの試 験科目毎に一定水準以上のものを合格者とする」と 定められていた。これに対し，6 年制薬剤師国家試 験のあり方として以下の内容が発表された。「薬学 教育年限の延長とそれに伴って薬剤師国家試験の受 験資格が見直された趣旨に照らし，薬剤師国家試験 を通じて，基礎的な知識や技術はもとより，高い倫 理観，医療人としての教養，医療現場で通用する実 践力などを確認する必要がある。また，多様かつ複 雑な医療の実際において, 薬剂師が医療の担い手と して真に役割を果たすには，時として自らが有する 知識等の範囲を超える未知の事象・事案に対して, 6 年制課程で習得した知識・技能・態度等を最大限 発揮して, 資格者として責任ある行動をとることが 求められる。薬剤師国家試験を通じて, 薬剤師資格 
を有する者として必要とされる基本的な知識等のほ か，薬学の全領域に及ぶ一般的な理論や，医療を中 心とした実践の場において必要とされる知識・技 能・態度等を確認する必要がある。また，薬学に関 する基本的な知識等と実践に関する総合的能力が体 系的に習得されているか否かを確認することも重要 である」. ${ }^{2)}$ この内容から，これからの薬剤師には基 礎的な知識や技術だけでなく，(1)高い倫理観，(2)医 療人としての教養，(3)医療現場で通用する実践力, が求められていることが読み取れる。しかし，科目 毎及び現行の薬学教育の枠内での知識修得だけで は，求められている薬剤師を育成することができな い，そこで，従来の科目の壁を越え，臨床を見据え て行動をすることができる薬剤師を育成していくシ ステムが求められる。 さらには，そのシステムで育 成された薬剤師が，臨床で必要とされる医薬品を開 発の場に提案できる広い視野を持てることを期待す る．今回は，糖尿病をテーマに教育現場・臨床・医 薬品開発，それぞれの役割及び共有すべきことにつ いて考え，本稿では，薬学教育で伝えるべき糖尿病 の基礎知識についてまとめた.

\section{2. 手法}

臨床を見据えた薬剤師を育成するため, 弊校が取 り組んできたことの一部を手法として以下に示す。

手法 1） 処方勉強会

薬剂師を育成する立場である講師が科目の壁を越 え，臨床的知識を修得するため，処方勉強会を実施 した. ${ }^{3)}$ 川越，渋谷，八王子，お茶の水，池袋，名 古屋，大阪，神戸，福岡の 9 教室をテレビ会議シス テムで接続し，全科目（基礎化学系，基礎生物系， 衛生薬学, 法規・制度, 医療薬学) の講師が参加し, 1 日 1 疾患の基礎勉強会に続いて，模擬処方せんを 使用して処方解析，疑義対応及び患者対応のシミュ レーションを実施した。勉強会には臨床薬剤師の方 にご参加頂き，臨床現場での着目点及び患者への服 薬指導等について指導して頂いた. ${ }^{4)}$ 到達度を評価 するために，教室毎に症例・処方をべースとした総 合問題を作成した．また，作成意図を発表する機会 を設け，意見交換を実施した。

手法 2）総合講義

1 日の講義スケジュールを 1 つの疾患（臓器）に 関連づけて設定し，基礎から臨床までの関係をつな げて理解することを到達目標とした総合講義を実施
Table 1. Schedule of Integrated Lecture

\begin{tabular}{|c|c|}
\hline Subject & Content of lecture \\
\hline $\begin{array}{l}\text { Functional } \\
\text { morphology }\end{array}$ & $\begin{array}{l}\text { Structure and function of pancreas } \\
\text { Receptors and action of insulin }\end{array}$ \\
\hline Biochemistry & $\begin{array}{l}\text { Glucose metabolism } \\
\text { (production of ketone) }\end{array}$ \\
\hline $\begin{array}{l}\text { Preventive } \\
\text { pharmacy }\end{array}$ & $\begin{array}{l}\text { Improvement of lifestyle, Preventive } \\
\text { medical care (metabolic syndrome) }\end{array}$ \\
\hline Pathophysiology & $\begin{array}{l}\text { Pathophysiology of diabetes (differences } \\
\text { between type } 1 \text { and } 2 \text { diabetes) }\end{array}$ \\
\hline Drug therapeutics & Therapeutic methods of diabetes \\
\hline Pharmacology & $\begin{array}{l}\text { Pharmacologic action and side effects } \\
\text { of therapeutic drug }\end{array}$ \\
\hline $\begin{array}{l}\text { Pharmacist duties } \\
\text { in hospital }\end{array}$ & $\begin{array}{l}\text { Prescription and patient compliance } \\
\text { instruction on diabetes }\end{array}$ \\
\hline
\end{tabular}

The lecture was designed according to one theme. As a result, information between subjects is shared. This is an example of a lecture that featured the theme of diabetes.

した，例として，糖尿病をテーマとした総合講義の スケジュールを Table 1 に示す.

\section{3. 各論}

本稿では，テーマである糖尿病について，処方勉 強会や総合講義を実施する中で共有した科目間の知 識や臨床的視点を踏まえて，薬学教育モデル・コア カリキュラムにおける Specific Behavioral Objective （SBO ; 到達目標）を示しながら，薬学教育で伝え るべき病態生理，薬物治療等をまとめる.

SBO : 主要なホルモンの分泌機構及び作用機構 を説明できる.

糖尿病とはインスリンの作用不足による慢性の高 血糖状態を主徴とする代謝疾患群である. ${ }^{5)}$ まずは じめに，糖尿病の病態に深く係わるインスリンの分 泌機構について学習する．インスリンの分泌機構を Fig. 1 に示す．血中グルコースが膵臓 B 細胞にある 糖輸送単体 glucose transporter 2 (GLUT2) により B 細胞内に取り込まれるとグルコースの代謝により ATP が産生される。ATP 感受性 $\mathrm{K}^{+}$チャネルが ATP によって閉口し，生じた活動電位が $\mathrm{Ca}^{2+}$ チ ヤネルを開口し， $\mathrm{Ca}^{2+}$ が流入する，細胞内 $\mathrm{Ca}^{2+}$ 濃度が上昇することでインスリンが分泌する. ${ }^{6,7}$

次に分泌されたインスリンが血糖值を低下させる 機序を学習する．膵臓 B 細胞から分泌されたイン スリンは $\mathrm{A}$ 鎖， $\mathrm{B}$ 鎖からなるポリペプチドがジス ルフィド結合でつながつた構造を有する。 ${ }^{8)}$ インス 
リン受容体とグルコースの取り込み機序を Fig. 2 に示す，インスリン受容体は，チロシンキナーゼ内 蔵型であり，各 2 個の $\alpha$ 及び $\beta$ サブユニットから なり，各サブユニットはジスルフィド結合で結合し ている. ${ }^{6,7)}$ インスリンがインスリン受容体のインス リン結合部位に結合すると，チロシンキナーゼが 活性化され，基質である insulin receptor substrate （IRS；インスリン受容体基質）がリン酸化される. Phosphatidylinositol-3-kinase（PI3k）はリン酸化さ れた IRS と結合して活性化され，phosphatidylinositol-3,4,5-trisphosphate (PIP3) 濃度を上昇させる. 続いて, 3-phosphoinositide-dependent protein kinase1 (PDK1), Akt（別名：protein kinase B; PKB) が

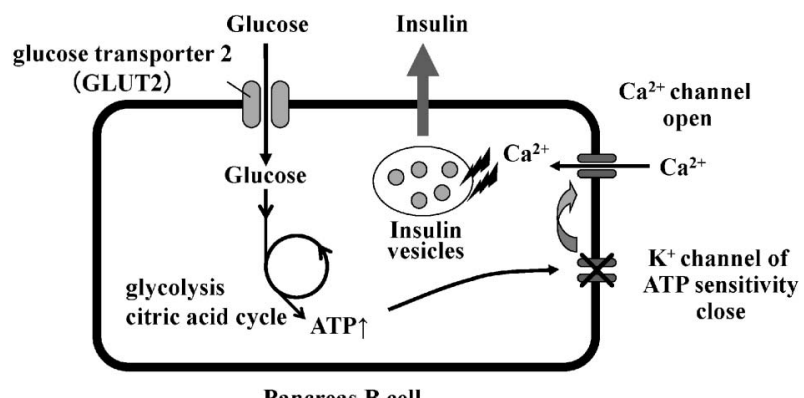

Pancreas B cell

Fig. 1. Mechanism of Insulin Secretion

The action of Sulfonylureas can be understood from knowing the mechanism of the insulin secretion.
活性化される．Aktがリン酸化されると，小胞が細 胞膜へ移動し, 細胞膜と融合することで小胞内の糖 輸送単体 glucose transporter 4 （GLUT4）が膜表面 に現れ，筋肉・脂肪細胞内にグルコースが取り込ま れ，血糖值が低下する。 ${ }^{9-11)}$

$\mathrm{SBO}$ : 糖尿病とその合併症の病態生理，適切な 治療薬及び使用上の注意について説明できる。

糖尿病の病態生理，治療薬等について学習する上 で，臨床的な視点で考えるためには，具体的な患者 設定が重要である．Table 2 に学習を進めるにあた り患者を意識できるよう典型的な糖尿病患者の症例 を示す。

糖尿病は 1 型と 2 型に大別される. Table 3 に糖 尿病における 1 型と 2 型の違いを示す。 1 型は糖尿 病の $5 \%$ 以下を占め，若年者に発症することが多 い. 膵臓の B 細胞の破壊に伴いインスリン分泌不 全が生じるため，治療にはインスリン自己注射が必 要となる。 また，ケトン体の増加に伴うケトーシス 傾向が現れ易い。一方， 2 型は糖尿病の $95 \%$ 以上を 占め，中高年に発症することが多く，インスリン抵 抗性やインスリン分泌低下が関与する. ${ }^{12)}$ インスリ ン抵抗性とは，血中インスリン濃度に見合ったイン スリン作用が得られない状態を指し，肥満の関与が 大きいとされる. ${ }^{12)}$ 肥満により小型脂肪細胞が大型 脂肪細胞に変わり，小型脂肪細胞から分泌されてい



Fig. 2. Insulin Receptor and Glucose Transport

When insulin binds with the receptor, the glucose is taken into the cell through the activation of the protein tyrosine kinase. Abbreviations: IRS (insulin receptor substrate), PI3k (phosphatidylinositol-3-kinase), PIP3 (phosphatidylinositol-3,4,5-trisphosphate), PDK1 (3-phosphoinositide-dependent protein kinase-1), Akt (protein kinase B; PKB), GLUT4 (glucose transporter 4). 
Table 2. Typical Case of Diabetes

【Case】

50-years-old man. Five years ago, disclosure of the glycosuria by the medical examination at the workshop, but he has neglected it. A consultation as an ambulant for the swelling of his feet continuing for 3 days. He tells swelling of feet, pollakiuria, dry mouth. Stature $172 \mathrm{~cm}$, body weight 86 $\mathrm{kg}$, finding of the swelling of the legs.

Pulse rate $48 / \mathrm{min}$, blood pressure $188 / 99 \mathrm{mmHg}$.

Urinalysis: protein $2+$, glucose $2+$, ketone $(-)$.

Blood test: fasting blood glucose $200 \mathrm{mg} / \mathrm{dl}, \mathrm{HbA}_{1 \mathrm{c}} 7.0 \%$, BUN $20 \mathrm{mg} / \mathrm{dl}, \mathrm{Scr} 1.0 \mathrm{mg} / \mathrm{dl}, \mathrm{Na}^{+} 144 \mathrm{mEq} / \mathrm{l}$, $\mathrm{K}^{+} 3.0 \mathrm{mEq} / 1, \mathrm{Cl}^{-} 111 \mathrm{mEq} / 1$

It aims for the pharmacist who can consider the patient by studying the disease while seeing the case. Abbreviations: $\mathrm{HbA}_{1 \mathrm{c}}$ (hemoglobin $\mathrm{A}_{1 \mathrm{c}}$ ), BUN (blood urea nitrogen), Scr (serum creatinine).

Table 3. Differences between Type 1 and Type 2 Diabetes

\begin{tabular}{c|c|c}
\hline \hline Classification & Type 1 & \multicolumn{1}{c}{ Type 2 } \\
\hline Epidemiology & Less than 5\% & More than 95\% \\
\hline Mechanism & $\begin{array}{l}\text { Destruction of the pan- } \\
\text { creas B cell by the au- } \\
\text { toimmunity } \\
\text { Absolute lack of in- } \\
\text { sulin }\end{array}$ & $\begin{array}{l}\text { Genetic agents lower- } \\
\text { lne secretion of insu- } \\
\text { lin with the addition } \\
\text { of the environmental } \\
\text { factors cause the lack } \\
\text { of insulin }\end{array}$ \\
\hline
\end{tabular}

Family medical Less than the case of Diabetes related to the

\begin{tabular}{|c|c|c|}
\hline history & type 2 & family medical history \\
\hline Age of & $\begin{array}{l}\text { Frequ } \\
\text { cy to }\end{array}$ & $\begin{array}{l}\text { More than 40-years- } \\
\text { old }\end{array}$ \\
\hline $\begin{array}{r}\text { Participa } \\
\text { obes }\end{array}$ & No relati & $\begin{array}{l}\text { Related to obesity or } \\
\text { past obesity }\end{array}$ \\
\hline K & $\mathrm{D}$ & Mostly \\
\hline Autoantibody & Anti-GAD antibody & $(-$ \\
\hline
\end{tabular}

Type 2 diabetes develops easily over 40 -years-old and obesity. Type 2 diabetes often shows the insulin resistance. Abbreviation: GAD (glutamic acid decarboxylase)

たアディポネクチンが減少し，大型脂肪細胞から分 泌される腫瘍壊死因子 $\alpha$ (Tumor Necrosis Factor $\alpha$; $\mathrm{TNF} \alpha$ ）等が増加する.これに伴い，インスリン抵 抗性が増大し, 動脈硬化が促進する. ${ }^{13,14)} 2$ 型糖尿 病の治療は, まずはじめに食事療法・運動療法が行 われ，ついで経口糖尿病薬が用いられる。また， 2 型糖尿病患者においても妊娠，過度の高血糖等では インスリン製剤が用いられる. ${ }^{5,15)}$ Table 2 に示した 症例においては, 50 歳という患者の年齢, ケトン 体 $(-)$ 及び身長・体重より求めた体格指数 $[\mathrm{BMI}$
$=$ 体重 $\left.\mathrm{kg} /(\text { 身長 } \mathrm{m})^{2}\right]$ が 29.07 を示すことより 2 型糖尿病の可能性が示唆される.

糖尿病の症状として，口渇，多飲，多尿及び全身 倦意感等がみられる。血糖值の上昇に伴い組織内の 水分が血中に移行し口渇，多飲が生じ，尿細管内の 血糖上昇に伴い尿中に排泄される水分量が増加する ことで多尿が生じる. Table 2 に示した症例におい ては，トイレが近く，喉の渴きを自覚しているた め，口渇，多尿の症状を確認できる.

糖尿病の急性合併症として, 糖尿病昏睡及び感染 症等がみられる。糖尿病昏睡のうち糖尿病ケトアシ ドーシスは, 糖利用の低下により脂質代謝が充進 し, ケトン体（アセト酢酸，3-ヒドロキシ酪酸）が

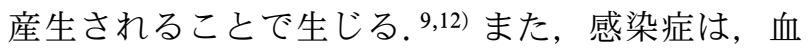
糖值の上昇により顆粒球の食食能が低下するために 生じる. ${ }^{13)}$

糖尿病の三大合併症として, 神経障害, 網膜症, 腎症がみられる。合併症の原因としては多くの仮説 が提唱されているが，本稿では神経障害に適応を有 する治療薬があるためポリオール経路の亢進につい てまとめる。慢性高血糖状態になるとポリオール経 路を介したグルコースの代謝が行われる.グルコー スがアルドース還元酵素によりソルビトールに変換 され，細胞機能障害が生じると考えられている. ${ }^{12)}$

SBO：代表的な内分泌 - 代謝疾患に関する検査 を列挙し, その検査值の異常から推測される主な疾 病を挙げることができる.

検査值より患者の状態を推測するためには，糖尿 病の診断基準を学ぶ必要がある. Table 4 に糖尿病 の診断基準を示す. 5) Table 2 に示した症例において は, 空腹時血糖值が $200 \mathrm{mg} / \mathrm{dl}$ を示し, 口渇, 多尿 等, 糖尿病の典型的な症状がみられ, かつ同時に測 定した $\mathrm{HbA}_{1 \mathrm{c}}$ が $6.5 \%$ 以上を示すため, 糖尿病患者 であることが診断できる.

SBO：代表的な糖尿病治療薬を挙げて作用機序 と主な副作用について説明できる.

ここまでの学習で Table 2 に示した症例は, 肥満 が原因で発症した 2 型糖尿病の可能性が高いことを 確認することができた，次のステップとしてこの患 者に出された処方せんを提示し, 糖尿病治療薬につ いて学んでいく. 処方せんを Fig. 3 に示した. 処 方 No. 1 のアマリール（グリメピリド）は，スル ホニル尿素（SU）薬である. SU 薬は，インスリン 
分泌機構（Fig. 1）において，ATPを介さずに ATP 感受性 $\mathrm{K}^{+}$チャネルを閉口することでインス リンの分泌を促進する。血糖非依存的にインスリン

Table 4. Diagnostic Criteria for Diabetes

(1) Fasting blood glucose in early morning: $126 \mathrm{mg} / \mathrm{dl} \leqq$

(2) $75 \mathrm{~g}$ oral glucose tolerance test (2 hours value): $200 \mathrm{mg} / \mathrm{dl} \leqq$

(3) Any time blood glucose level: $200 \mathrm{mg} / \mathrm{dl} \leqq$

- When either of (1)-(3) mentioned above was reaffirmed by inspection performed on another day, it is diagnosed diabetes. ※It is diagnosed as a diabetes type when it was confirmed only.

- But, in the case of either of next 1)-4), it is diagnosed as diabetes for the diabetes type.

1) When there is a typical symptom of diabetes such as mouth dryness, polyposia, polyuria, losing weight.

2) When $\mathrm{HbA}_{1 \mathrm{c}}$ measured at the same time is more than $6.5 \%$.

3) When a certain diabetes retinopathy is accepted.

4) When there is data that showed the diabetic type in the past.

- Even if current blood glucose level is less than the criteria of the diabetes type, when there is the condition mentioned above in the past the diabetes is suspected.

Blood glucose level and $\mathrm{HbA}_{1 \mathrm{c}}$ are used for the diagnostic criteria for diabetes. Moreover, the symptom becomes one of the important factors, too. Abbreviation: $\mathrm{HbA}_{1 \mathrm{c}}$ (hemoglobin $\mathrm{A}_{1 \mathrm{c}}$ ).
分泌を促進するため，低血糖を起こす危険性があ る. ${ }^{11,16)}$ 処方 No. 2 のグルコバイ（アカルボース） は，食後過血糖改善薬である。二糖類分解酵素の $\alpha$-グルコシダーゼを阻害して，糖の吸収を遅延させ るため，食後の過血糖を是正する．副作用として， 腸内ガスの産生により生じる腹部膨満感，放屁の増 加等，腸閉塞様症状が知られている．また，食直前 の服用が必要である. ${ }^{11,16)}$ 他剂との併用時に生じる 低血糖には砂糖，あめ（二糖類）は無効であり，ブ ドウ糖（単糖）を服用しなければ速やかな回復は認 められない. ${ }^{11)}$ 処方 No. 3 のメルビン（メトホルミ ン）は，ビグアナイド系薬である．筋肉や脂肪組織 での糖の利用を促進し, 肝臓での糖新生, 糖放出を 抑制する．副作用として乳酸アシドーシスがあり， 一時期使用が減っていたが体重増加が生じ難い等の 特徵により，見直されてきている. ${ }^{11,16)}$ 処方薬以外 に糖尿病の治療薬として，速効型インスリン分泌促 進薬のスターシス，ファスティック（ナテグリニ ド),グルファスト (ミチグリニド)，チアゾリジン 系薬のアクトス（ピオグリタゾン），末梢神経障害 の治療に用いられるアルドース還元酵素阻害薬のキ ネダック（エパルレスタット）等がある。速効型イ ンスリン分泌促進薬は SU 薬と同様の作用である が，吸収と血中からの消失が速いという特徵を持 ち，食直前に服用することで食後の血糖上昇を抑え

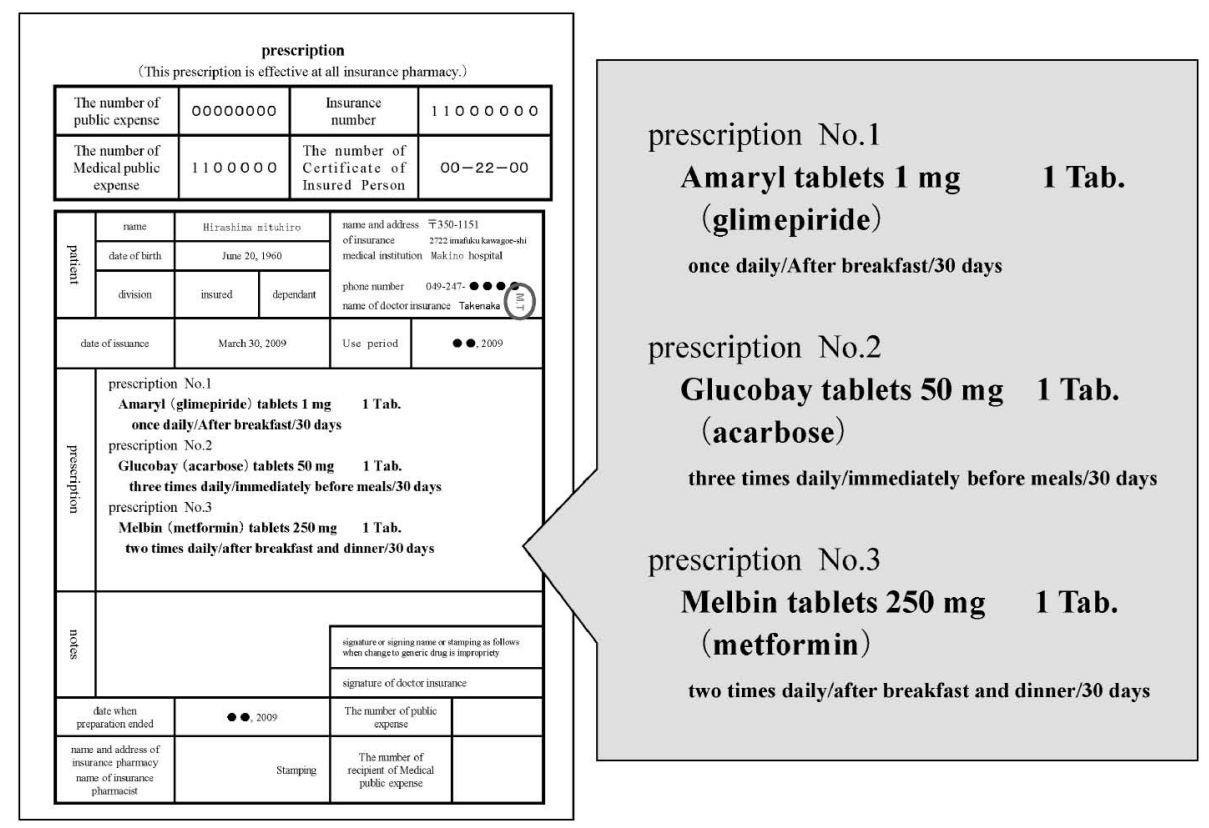

Fig. 3. Typical Prescription of Type 2 Diabetes There are a lot of kinds of diabetic drugs. It is important to know the feature to use them correctly. 
ることができる. ${ }^{11,16)}$ チアゾリジン系薬は肥満によ るインスリン抵抗性のみられる患者に適している. インスリン受容体活性化, 筋肉での糖利用促進, 肝 臓での糖新生抑制といつた作用以外に核内転写因子 ペルオキシソーム増殖活性化受容体 $\gamma$ (Peroxisome Proliferator-Activated Receptor $\gamma ; \operatorname{PPAR} \gamma)$ を促進 して前駆脂肪細胞から小型脂肪細胞への分化を促進 し，大型脂肪細胞への分化を抑制することで，アデ イポネクチンを増加させ， $\mathrm{TNF} \alpha$ 等を減少させるた め，インスリン抵抗性を改善する.11,16,17）また， PPAR $\gamma$ 活性化により抗動脈硬化作用も発現す る. ${ }^{18,19)}$ Figure 4 にチアゾリジン系薬の作用を示す.

$\mathrm{SBO}$ : 医薬品に含まれる代表的な官能基をその 性質によって分類し, 医薬品の効果を結びつけて説 明できる。

SU 薬は，構造式に共通してスルホニルウレアを 有する.アマリールの構造式と官能基を Fig. 5 に 示した. ${ }^{11,16)}$

SBO：入手した情報を評価し，患者に対してわ かり易い言葉，表現で適切に説明できる.

Figure 3 の処方を用いて実際に服薬指導を体験す る。弊校で実施した処方勉強会で実際に服薬指導に 挑戦した多くの講師が，患者に対してわかり易い言 葉，表現を用いて説明するためには，患者とのコミ
ユニケーションスキルが重要であることを実感した。 6 年制薬学教育では, 実務実習における実践に基づ いたスキルの向上が期待される。

\section{4. まとめ}

6 年制教育に CBT や OSCE 等の共用試験や長期 実務実習が導入され，薬学教育の中で，チーム医療 の一員として基礎的な知識や技術を身につけるだけ でなく，(1)高い倫理観，(2)医療人としての教養，(3) 医療現場で通用する実践力を持つ薬剂師を育成する ことが求められている.

患者のための医療の実現, さらに医薬品開発の場 にも臨床現場が必要とする医薬品を提案できる薬剤 師を育成するためには，有機化学や薬理学といつた

\begin{tabular}{|l|}
\hline prescription No.1 \\
Amaryl tablets $1 \mathrm{mg} \quad \mathbf{1}$ Tab. \\
(glimepiride) \\
once daily/After breakfast/30 days
\end{tabular}

SU ( sulfonylurea )

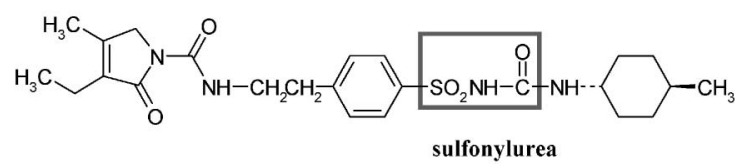

Fig. 5. Structural of Amaryl Sulfonylureas has the structure formula of sulfonylurea.

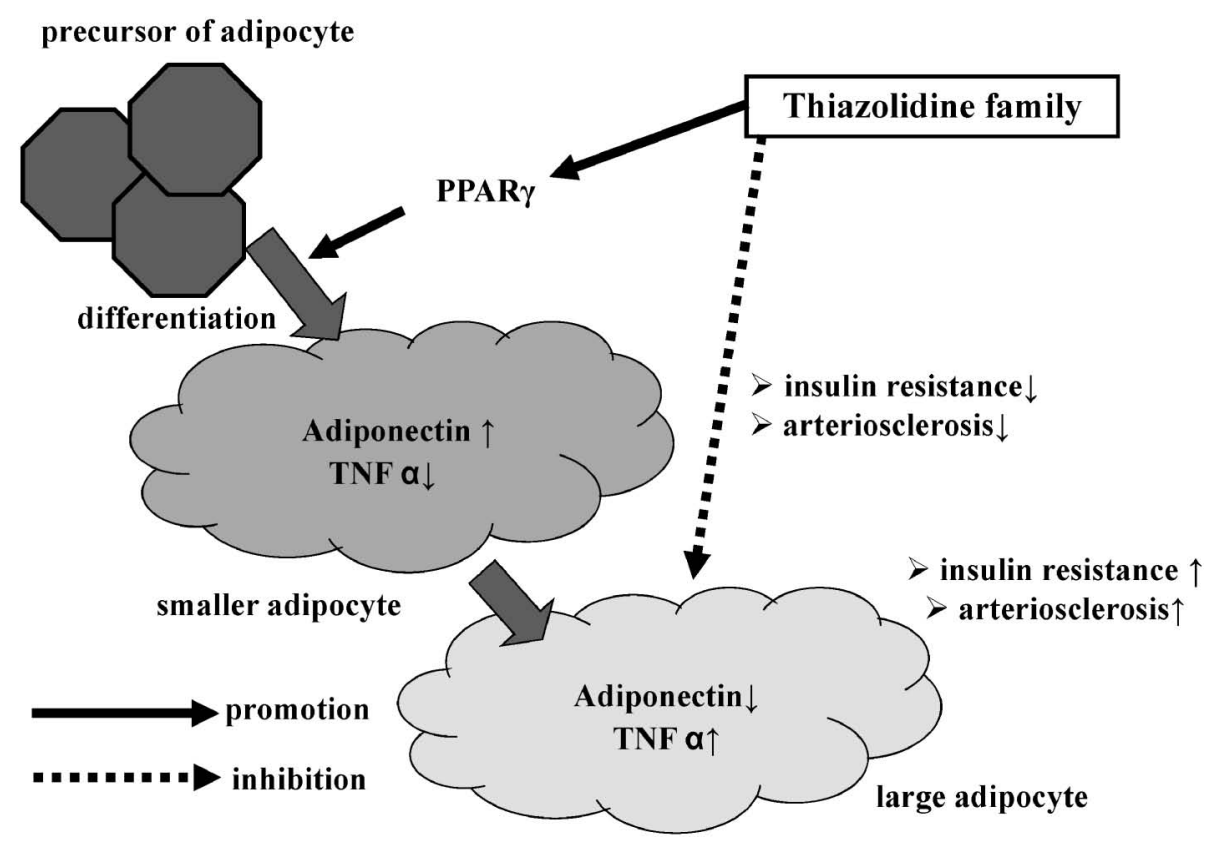

Fig. 4. Action System of Thiazolidinedione Family

Thiazolidinedione promotes the action of PPAR $\gamma$, increases the secretion of adiponectin, and controls the secretion of TNF $\alpha$. Abbreviations: PPAR $\gamma$ (peroxisome proliferator-activated receptor $\gamma$ ), TNF $\alpha$ (tumor necrosis factor $\alpha$ ). 
従来の科目の壁を越え，臨床を意識した指導を行う 必要がある.また, 薬学教育, 臨床現場（病院並び に薬局等)，医薬品開発の現場（大学並びに製薬会 社等)が連携を取り，様々な領域から「患者の症状・ 疾患を治療する」ために意見を交換し，情報を共有 することが重要である。

\section{謝辞本稿を終えるにあたり，ともに薬学教育} について考え，シンポジウムを企画して下さった京 都薬科大学分析薬科学系代謝分析学分野講師吉川 豊先生に謹んで感謝致します。また，終始御朁篤な るご指導とご鞭撻を賜りました岡山大学大学院医歯 薬学総合研究科准教授加来田博貴先生, 京都薬科大 学生薬学教室助教中村誠宏先生, 財団法人倉敷成人 病センタ一薬剤部副主任原田七穂先生，味の素株式 会社健康基盤研究所天然物素材研究グループ安達祐 介様に謹んで感謝の意を表します。さらに，本シン ポジウムに参加するにあたり，ご支援とご協力を賜 りました医学アカデミー薬学ゼミナール副学長木暮 喜久子を始め, 薬学ゼミナールの諸氏に心より感謝 申し上げます。

\section{REFERENCES}

1) Pharmacists Law: 〈http://hourei.hounavi.jp/ hourei/S35/S35HO146.php $\rangle$, Legal Media Co., Ltd. Web, cited 1 July, 2010.

2) Ministry of Health, Labour and Welfare: 〈http://www-bm.mhlw.go.jp/shingi/2008/07 /dl/s0708-5a.pdf $\rangle$, cited 30 March, 2011.

3) Murakami A., Deguchi H., Hirashima M., Kogure K., Abstracts of papers, the 129th Annual Meeting of the Pharmaceutical Society of Japan, Kyoto, March 2009, part 4, p. 325.

4) Deguchi H., Nakamura F., "OSCE Visual Guide: Chozai no Nagare to Shugi," Yakuzemi Joho Kyoiku Center, Tokyo, 2009.

5) “Tonyobyo Chiryo Guide 2008-2009," ed. by
Japan Diabetes Society, Bunkodo Co., Ltd., Tokyo, 2008.

6) Ochi R., "Seirigaku Text,"' 4th ed., Bunkodo Co., Ltd., Tokyo, 2006, pp. 411-414.

7) Hongou T., Hiroshige T., Toyoda J., "Hyojun Seirigaku," 6th ed., Igaku-Shoin Ltd., Tokyo, 2007, pp. 932-938.

8) Mathews C. K., van Holde K. E., Ahern K. G., "Biochemistry," Nishimura Co., Ltd., Niigata, 2003, p. 110.

9) Murray R. K., Granner D. K., Mayes P. A., Rodwell V. W., 'Harper's Illustrated Biochemistry, 27th ed.,'” Maruzen Co., Ltd., Tokyo, 2007, pp. 146-159.

10) Saltiel A. R., Kahn C. R., Nature, 414, 799806 (2001).

11) Davis S. N., “Goodman \& Gilman's The Pharmacological Basis of Therapeutics, 11th ed.," eds. by Brunton L. L., Lazo J. S., Parker K. L., Hirokawa Shoten, Tokyo, 2007, pp. 2063-2106.

12) Kasper D. L., Fauci A. S., Longo D. L., Braunwald E., Hauser S. L., Jameson J. L., "Harrison's Principles of Internal Medicine," Medical Sciences International, Ltd., Tokyo, 2006, pp. 2212-2242.

13) Yamagishi S., Nippon Rinsho, 68, 307-311 (2010)

14) Waki H., Yamauchi T., Kadowaki T., Nippon Rinsho, 68, 210-216 (2010).

15) Suzuki K., Asakura T., Yakkyoku, 60 (4, Suppl.), 550-562 (2009).

16) Tanaka C., Kato R., "New Pharmacology," Nankodo Co., Ltd., Tokyo, 2007, pp. 498501.

17) Fukushima Y., Urakaze M., Tobe K., Nippon Rinsho, 68, 299-304 (2010).

18) Wakino S., Itoh H., Nippon Rinsho, 68, 217223 (2010).

19) Kawamori R., Nippon Rinsho, 68, 235-241 (2010) . 